\title{
Dogs poisoned with Nerium oleander fresh leaves: clinical and electrocardiographic findings
}

\author{
Annelise Carla Camplesi ${ }^{1 *}$ Carolina Bellodi $^{1}$ José Javier Mesa Socha $^{1}$ Mário Roberto Hatayde ${ }^{1}$ \\ Márcia Ferreira da Rosa Sobreira ${ }^{1}$ Gustavo Henrique Marques Araujo ${ }^{2}$ Carla Fredrichsen Moya Araujo ${ }^{3}$
}

'Departamento de Clínica Médica Veterinária, Univesidade Estadual Paulista “Júlio de Mesquita Filho" (UNESP), Via de Acesso Prof. Paulo Donato Castellane, s/n, 14884-900, Jaboticabal, SP, Brasil. E-mail: annecamplesi@yahoo.com.br. "Corresponding author. ${ }^{2}$ Departamento de Clínica Médica Veterinária, Universidade Federal do Goiás (UFG), Jataí, GO, Brasil.

${ }^{3}$ Departamento de Medicina Veterinária, Universidade Estadual do Centro-Oeste (UNICENTRO), Guarapuava, PR, Brasil.

\begin{abstract}
Nerium oleander is distributed worldwide, mainly in tropical and subtropical regions. These shrubs are frequently used as ornamental plants. However, they contain more than 30 cardiac glycosides that can cause serious toxic effects in dogs. The objective of this study was to report the clinical and electrocardiographic alterations in dogs experimentally poisoned with N. oleander. Ten adult, healthy, mixed-breed dogs weighing 10$25 \mathrm{~kg}$ and aged 3-6 years were selected for the study. We orally administered $0.25 \mathrm{~g} \mathrm{~kg}^{-1}$ of fresh ground leaves of $N$. oleander to the dogs. No dog died after the ingestion, but all exhibited signs of poisoning such as vomiting, sialorrhea, nausea, apathy, conjunctiva congestion, dehydration, abdominal pain, tremors, diarrhea, loss of appetite, and tenesmus. Electrocardiogram revealed occurrence of several types of arrhythmias: sinus bradycardia, second-degree atrioventricular block, paroxysmal ventricular tachycardia, and ventricular premature complexes. Systolic blood pressure, as well

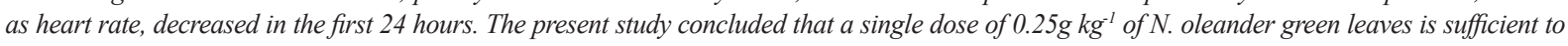
cause a moderate intoxication in dogs, with nonspecific clinical changes mainly related to the digestive system and heart rate, thus demonstrating the importance of this type of intoxication in the list of differential diagnoses of small animals routine.
\end{abstract}

Key words: blood pressure, arrhythmia, electrocardiography, cardiac glycosides, canine.

Cães intoxicados com folhas frescas de Nerium oleander: achados clínicos e eletrocardiográficos

RESUMO: O Nerium oleander é uma planta com ampla distribuição mundial, principalmente em regiões tropicais e subtropicais. Esses arbustos são frequentemente usados como plantas ornamentais e possuem mais de 30 glicosídeos cardíacos causadores do quadro clínico de intoxicação em caninos. Sabendo-se disso, este artigo teve por objetivo a avaliar as alterações clínicas e eletrocardiográficas, nos animais intoxicados experimentalmente com $\mathrm{N}$. oleander. Foram utilizados 10 cães adultos, hígidos, sem raça definida, com 10 a $25 \mathrm{~kg}$ de peso, de 3 a 6 anos de idade. Os animais receberam uma única dose de $0,25 \mathrm{~g} \mathrm{~kg}^{-1}$ de peso, de folhas frescas de $\mathrm{N}$. oleander. Nenhum dos animais do experimento veio a óbito. Os sinais clínicos observados foram vômito, sialorréia, náuseas, apatia, conjuntiva ocular congesta, desidratação, dor abdominal, tremores, diarreia, inapetência e tenesmo. Pela análise do eletrocardiograma encontraram-se arritmias como: bradicardia sinusal, bloqueios atrioventriculares de segundo grau, taquicardia ventricular paroxística e complexo ventricular prematuro. A pressão arterial sistólica diminui nas primeiras 24 horas, assim como a frequência cardíaca. Concluiu-se com o presente estudo que uma única dose de $0,25 \mathrm{~g} \mathrm{~kg}^{-1}$ de folhas verdes de $\mathrm{N}$. oleander é suficiente para causar um quadro moderado de intoxicação em cães, com alterações clínicas inespecíficas principalmente relacionadas ao sistema digestório e no ritmo cardíaco, mostrando a importância deste tipo de intoxicação na lista de diagnósticos diferenciais da rotina de pequenos animais. Palavras-chave: pressão sanguínea, arritmia, eletrocardiografia, glicosídeos cardíacos, canino.

\section{INTRODUCTION}

Dog poisoning is becoming more common and frequent in the small animal practice, representing an important component in the clinic casuistry, especially when considering home accidents, involving contact with cleaning chemical products and ornamental toxic plants. Both dogs and cats are potentially exposed to the risk of consuming toxic plants or its parts, especially puppies, which are far more curious. Adult dogs and cats can ingest toxic plants due to behavioral disorders or in cases of alimentary disturbances (LYNN \& SAFDAR, 2006).
$N$. oleander is an ornamental plant and can cause cardiovascular disorders due to the presence of cardiac glycosides in 45 different species of this plant, which are toxic to human and animals (MARTINEZ et al., 2007).

Despite of the plant's poor palatability, it could be ingested by hungry or bored animals, leading to poisoning symptoms (LYNN \& SAFDAR, 2006). Cardiac glycosides are chemically similar to digoxin, and are distributed throughout the plant, either fresh or dried (LANGFORD \& BOOR, 1996; SOTOBLANCO et al., 2006). IBRAHIM et al. (2008) 
described 30 different types of glycosides classified as oleandrines, digitoxigenines, and folinerines.

A simple contact of the plant with the intact skin or mucosa causes mouth erythema, contact dermatitis, sickness, vomiting, sialorrhea, abdominal pain, headache, mental disorders, visual problems, mydriasis, neuritis, and serious cardiovascular disorders(HUGHES etal., 2002;ASLANI etal., 2007). Cardiovascular signs originate due to the activity of the cardiac glycosides. Their mechanism of action is based on the inhibition of sodium-potassium pump (Na/K-ATPase), resulting in depletion of intracellular potassium and increased level of intracellular sodium. These cellular changes lead to cytoplasmic calcium accumulation, responsible for the positive inotropic heart effect. Electrolytic imbalance modifies the electrical conduction in the heart (LANGFORD \& BOOR, 1996). In these conditions, the sympathetic response is increased, thus sensitizing the myocardium and enhancing the toxicity of the Nerium glycosides (JOUBERT, 1989; ASLANI et al., 2007). Reduced electrical conductivity of the myocardium can lead to conduction blockage such as ventricular arrhythmia and, eventually, a complete loss of contractibility (IBRAHIM et al., 2008).

Diagnosis of poisoning with the plants containing cardiac glycosides starts with the plant identification and proof of its consumption. This information could be obtained from anamnesis, clinical history, clinical signs, electrocardiography findings, clinical-pathologic alterations, and, in case of death, necropsy findings. Nevertheless, sometimes all these parameters are not enough to conclude a diagnosis (HUGHES et al., 2002).

The treatment of $N$. oleander poisoning is based on the oral or intravenous fluid therapy to reduce the cardiovascular alterations (HUGHES et al., 2002). Calcium-contained fluids should be avoided because the extra calcium could increase the effect of the cardiac glycosides on the myocardium (KNIGHT, 1988). Repeated doses of activated carbon are used to prevent enterohepatic recycling of the toxin (LYNN \& SAFDAR, 2006). Antiarrhythmic medications like atropine, atenolol, fentoine, procainamide and lidocaine could be used to control cardiac alterations (JOUBERT, 1989; PLUMB, 1999). However, the type of arrhythmia should be determined using the electrocardiographic exam (LANGFORD \& BOOR, 1996).

The aim of the present study was to evaluate the clinical and electrocardiographic alterations in dogs fed with $0.25 \mathrm{~g} \mathrm{~kg}^{-1}$ of ground $N$. oleander leaves added to the portion in a single dose/serve.

\section{MATERIALS AND METHODS}

The study was carried out according to the animal experimental ethical principles adopted by the Brazilian College of Experimentation (COBEA), of the São Paulo State University, UNESP - Jaboticabal, SP-Brazil.

Ten male and female healthy, mixedbreed, dogs, aged 3-6 years and weighing $10-25 \mathrm{~kg}$, were acquired from the Animal Research Center of Parasitology and Sanity - CPPAR/UNESP, Jaboticabal/SP-Brazil. Dogs were housed separately in kennels, with individual food and water bowls, at the Veterinary Hospital "Governador Laudo Natel" UNESP, Jaboticabal/SP-Brazil.

To determine the basal values of the electrocardiographic parameters and arterial pressure, the physical examination was performed at the pre-experimental period (T0h), just before the administration of the ground $N$. oleander fresh leaves. Same parameters were evaluated at the following experimental period: 4 hours (T4h), 24 hours (T24h), and 48 hours (T48h) after the administration.

Systolic arterial pressure (SAP), mean arterial pressure (MAP), and diastolic arterial pressure (DAP) were obtained by a non-invasive technique using oscillometric type device Dixtal ${ }^{\circledR}$, model DX2710 (Dixtal Manaus/AM, Brazil). SAP was also measured by another non-invasive method, the Doppler method. The dogs maintained in the right lateral decubitus, with cuff width about $40 \%$ of the left thoracic member circumference, placed at the distal portion of radius and ulna bones.

All five parameters were obtained at each time point (T0h, T4h, T24h, and T48h). Values determined as off the curve were discarded to obtain more exact mean values (TILLEY, 1992). During examinations, all animals were maintained at the same position with cuff position preserved at place for a non-invasive SAP acquiring using the vascular Doppler method, for five consecutive times, to posterior comparison with the SAP measured by oscilometric method.

A computer electrocardiography system was used applying peripherical derivations (I, II, II, aVR, aVL, and aVF) and precordial derivations (rV2, V2, V4, and V10). Electrocardiogram tracing was analyzed at bipolar derivation II (DII), with a speed of $50 \mathrm{~mm} \mathrm{~second}^{-1}$, calibrated for $1 \mathrm{~cm}$ equal to $1 \mathrm{mV}$, for 4 minutes, the time required to collect three measures of each electrocardiographic variable, and a mean of these analyses was evaluated. The observed cardiac rhythmic characteristics and parameters were: cardiac frequency, duration and amplitude of $\mathrm{P}$ wave, 
interval PR and QRS duration, amplitude of R wave, interval QT duration, polarity characteristic of $\mathrm{T}$ wave, presence or absence of segment ST depression, and the value in grade of QRS mean axis from I and III derivations. All electrocardiographic data were analyzed as described by TILLEY (1992).

Dogs were subjected to the same diet (commercial ration) during the experimental period. First clinical evaluation was performed 24 hours before the induction of poisoning with a single dose of ground $N$. oleander fresh leaves $\left(0.25 \mathrm{~g} \mathrm{~kg}^{-1}\right)$ with the ration. Monitoring continued for 48 hours after the administration. The T0h was established as the basal value measures for each animal before the feeding with the green leaves of $N$. oleander for posterior analyses and comparisons.

All animals received a bolus intravenous dose of $50 \mathrm{mg} \mathrm{kg}^{-1}$ of glucose, followed by continuous infusion of $10 \%$ glucose solution in physiological solution for 60 minutes, to obtain a dose of $10 \mathrm{mg}$ $\mathrm{kg}^{-1}$. In addition, the animals received supportive treatment, such as administration of antiemetic and fluid therapy, after the evaluation period.

Statistical analyses were performed using statistical program, comparing the mean values of the analyzed parameters after passing the normality test, using ANOVA for repeated measures, and Student Newman's Keuls (SNK) when necessary, with $5 \%$ of significance level. Qualitative observations were submitted to descriptive statistical analyses without comparisons.

\section{RESULTS AND DISCUSSION}

The presented clinical signs of poisoning with $N$. oleander were first noted 4 hours after the consumption and included: vomiting at $100 \%$ of the dogs (10/10); sialorrhea at $80 \%(8 / 10)$; nausea, apathy, conjunctiva congestion at $70 \% \quad(7 / 10)$; dehydration $50 \%(5 / 10)$, abdominal pain; tremors $30 \%(3 / 10)$; diarrhea $20 \%(2 / 10)$; and tenesmus at $10 \%$ of them $(1 / 10)$. Loss of appetite was noted in $30 \%(3 / 10)$ of the dogs even after the treatment. The first presented clinical sign was vomiting, within 27 75 minutes of administration of ground green leaves. Second observed sign was loss of appetite, after the intoxication and after the treatment, with $40 \%$ of the animals having these signs for as long as 12 hours after administration.

Other clinical evaluations like weight loss, temperature, time to capillary reperfusion, mucosa appearance, and respiratory frequency did not show significant alterations and were within the limits for the canine species.

The pressure measured using Doppler method did not reveal significant variation at the different time points. On the contrary, the evaluation performed using the oscillometric method demonstrated significant difference in the pressure $(\mathrm{P}<0.05)$ between the mean values collected at $\mathrm{T} 4 \mathrm{~h}$ and $\mathrm{T} 24 \mathrm{~h}$ time points for SAP, MAP, and DAP (Table 1), showing decrease of SAP and elevation of DAP.

At the interpretation and analyses of electrocardiogram tracing were found several alterations. All electrocardiographic alterations were resolved without antiarrhythmic treatment. The observed arrhythmias were: sinusal bradicardia, premature ventricular complex, second grade blockage, ventricular tachycardia, and sinusal tachycardia.

The analyses of the parameters monitored for the $10 \mathrm{dogs}$ indicated that, after the induced poisoning, $40 \%$ of the animals (4/10) presented sinusal bradicardia, 20\% (2/10) presented intermittent second grade blockage, 20\% (2/10) presented premature ventricular complex, $10 \%(1 / 10)$ presented sinusal tachycardia, and $10 \%$ of them $(1 / 10)$ presented paroxistic ventricular tachycardia.

Table 1 - Mean \pm standard deviation of SAP Doppler (mmHg), SAP (mmHg), MAP, and DAP (mmHg) measures, at time points T0h, T4h, $\mathrm{T} 24 \mathrm{~h}$ and $\mathrm{T} 48 \mathrm{~h}$ of dogs intoxicated with $N$. oleander.

\begin{tabular}{|c|c|c|c|c|c|}
\hline \multirow{2}{*}{ Arterial Pressure } & \multicolumn{4}{|c|}{---------------------------------------------------Moment---------------------------------------------- } & \multirow{2}{*}{ Reference Values } \\
\hline & T0h & $\mathrm{T} 4 \mathrm{~h}$ & $\mathrm{~T} 24 \mathrm{~h}$ & T48h & \\
\hline SAP Do. & $139.33^{\mathrm{a}} \pm 19.88$ & $136.99^{\mathrm{a}} \pm 16.66$ & $131.99^{\mathrm{a}} \pm 17.88$ & $141.66^{\mathrm{a}} \pm 19.12$ & $145 \pm 23 \mathrm{mmHg}$ \\
\hline SAP & $142.40^{\mathrm{a}} \pm 26.26$ & $104.60^{\mathrm{b}} \pm 29.27$ & $87.26^{\mathrm{b}} \pm 25.64$ & $146.13^{\mathrm{a}} \pm 29.33$ & $131 \pm 20 \mathrm{mmHg}$ \\
\hline MAP & $107.80^{\mathrm{b}} \pm 22.54$ & $86.40^{\mathrm{b}} \pm 24.24$ & $144.93^{\mathrm{a}} \pm 26.28$ & $107.80^{\mathrm{b}} \pm 23.93$ & $97 \pm 16 \mathrm{mmHg}$ \\
\hline DAP & $79.73^{b} \pm 26.04$ & $142.53^{\mathrm{a}} \pm 24.91$ & $105.40^{\mathrm{a}} \pm 21.01$ & $82.86^{\mathrm{b}} \pm 24.32$ & $74 \pm 15 \mathrm{mmHg}$ \\
\hline
\end{tabular}

SAP Do. $=$ systolic arterial pressure Doppler; $\mathrm{SAP}=$ systolic arterial pressure; $\mathrm{MAP}=$ mean arterial pressure; DAP $=$ diastolic arterial pressure. Reference values: BROWN et al. (2007). Different letters at the same line indicates a statistical difference with SNK test $(\mathrm{P}<0.05)$. 
Table 2 demonstrated the mean values and standard deviations of the electrocardiographic variables: duration of Pms wave, amplitude of Pmv, PR interval, QRS complex, Rmv wave amplitude, and QT interval. The data did not show significant statistical differences $(\mathrm{P}<0.05)$. However, the cardiac frequency has shown a value decrease at T4h.

The dose of $0.25 \mathrm{~g} \mathrm{~kg}^{-1}$ of ground $N$. oleander fresh leaves applied in the present study was not lethal for any dog. Some studies reported that using dry leaves or extracts with the active principle of the plant (oleandrine) in different concentrations induced intoxication symptoms (CLARCK et al., 1991). GALEY et al. (1996) considered N. oleander as a potentially toxic plant, because ingestion of $0.005 \%$ of dog's weight of dry leaves could lead to death. In the present study, we used fresh leaves to simulate a natural poisoning with this ornamental plant, estimated to contain more than thirty potentially toxic compounds.

The reported clinical signs observed in the present study were unspecific and could be confused with other types of poisoning and/or diseases. However, the clinical signs of $N$. oleander poisoning occur very fast after the ingestion of the leaves. LANGFORD \& BOOR (1996) mentioned in their research signs of vomiting, diarrhea, sialorrhea, apathy, central nervous system depression, hypotension, tremors, irregular pulse, and several arrhythmias, also observed in the present study. However, no worse consequences, such as coma or death, were observed in the present study, in contrast with the study of LANGFORD \& BOOR (1996). The difference probably came from the amount of the absorbed toxin, as described previously. In this study, all animals showed a clinical improvement after the treatment, confirmed by the return to the feed consumption.

The blood pressure measured using the Doppler and oscillometric methods, in the present study, stayed at normal levels during the whole experiment, which is in accordance with the results reported by BROWN et al. (2007) and GAINS et al. (1995). The oscillometric method had shown some differences between the values obtained at $\mathrm{T} 4 \mathrm{~h}$ and $\mathrm{T} 24 \mathrm{~h}$. These alterations are associated with the cardiac glycoside action, similar to the digoxin effect. These compounds increase the vagal tonus with an increase in parasympathetic effect, leading to inhibition of the sympathetic tonus and reduction in cardiac frequency and SAP (MERRETT, 2000). According to HABERMAN (2006), oscillometric method has a high correlation between the indirect measurements and the invasive method, which may have accuracy closer to that of the direct method. However, it is less accurate in case of hypotension.

In a study with anesthetized dogs, SHIH et al. (2010) used the oscillometric monitoring and observed less reliable accuracy compared to the invasive pressure monitoring, during the state of hypotension associated with acute hemorrhage. Doppler method is less accurate and can be used for PAS measuring only, while it appears to be a very poor PAD estimator. The device is further limited with the non-automatic character of the device and the absence of immediate response to sudden changes in pressure (DURHAM, 2005).

Various electrocardiographic changes related to $N$. oleander poisoning, including arrhythmias, such as bradycardia, blockages of first and second grade, premature ventricular complexes, ventricular tachycardia, sinus tachycardia, and

Table 2 - Mean \pm standard deviation of: Pms. Pmv. PR. QRS. Rmv. QT and cardiac frequency (CF) measures, at time points T0h, T4h, T24h and T48h of dogs intoxicated with $N$. oleander.

\begin{tabular}{|c|c|c|c|c|c|}
\hline \multirow{2}{*}{ Parameters } & \multicolumn{4}{|c|}{ 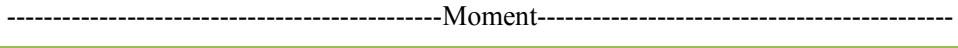 } & \multirow{2}{*}{ Reference Values } \\
\hline & TOh & T4h & $\mathrm{T} 24 \mathrm{~h}$ & T48h & \\
\hline $\mathrm{P}$ wave duration (ms) & $36.53^{\mathrm{a}} \pm 2.96$ & $39.60^{\mathrm{a}} \pm 3.02$ & $36.53^{\mathrm{a}} \pm 2.78$ & $34.06^{\mathrm{a}} \pm 3.33$ & Max $44.54 \mathrm{~ms}$ \\
\hline P wave amplitude (mv) & $0.12^{\mathrm{a}} \pm 0.03$ & $0.13^{\mathrm{a}} \pm 0.02$ & $0.13^{\mathrm{a}} \pm 0.02$ & $0.13^{\mathrm{a}} \pm 0.02$ & Max $0.20 \mathrm{mv}$ \\
\hline interval PR & $89.46^{\mathrm{a}} \pm 14.98$ & $113.80^{\mathrm{a}} \pm 15.01$ & $100.60^{\mathrm{a}} \pm 14.07$ & $104.73^{\mathrm{a}} \pm 13.20$ & 60 a $130 \mathrm{~ms}$ \\
\hline QRS & $50.86^{\mathrm{a}} \pm 4.80$ & $50.06^{\mathrm{a}} \pm 4.37$ & $51.33^{\mathrm{a}} \pm 4.28$ & $49.26^{\mathrm{a}} \pm 4.91$ & $54.78 \mathrm{~ms}$ \\
\hline $\mathrm{R}$ wave amplitude (mv) & $1.30^{\mathrm{a}} \pm 0.36$ & $1.22^{\mathrm{a}} \pm 0.30$ & $1.36^{\mathrm{a}} \pm 0.27$ & $1.20^{\mathrm{a}} \pm 0.35$ & $2.5 \mathrm{mv}$ \\
\hline interval QT & $206.73^{\mathrm{a}} \pm 20.34$ & $240.33^{\mathrm{a}} \pm 20.44$ & $223.40^{\mathrm{a}} \pm 19.13$ & $214.20^{\mathrm{a}} \pm 18.93$ & 150 a $250 \mathrm{~ms}$ \\
\hline $\mathrm{CF}$ & $102.53^{\mathrm{a}} \pm 24.62$ & $67.07^{b} \pm 19.33$ & $96.53^{\mathrm{a}} \pm 22.67$ & $84.13^{\mathrm{a}} \pm 23.33$ & 60 a $140 \mathrm{bpm}$ \\
\hline
\end{tabular}

$\mathrm{ms}=$ miliseconds; $\mathrm{mv}=$ millivolts; $\mathrm{CF}=$ cardiac frequency; Reference values: TILLEY (1992). Different letters at the same line indicates a statistical difference with SNK test $(\mathrm{P}<0.05)$. 
fibrillation, were observed in the present study. The arrhythmias originated due to the high inhibition grade of the $\mathrm{Na}^{+} / \mathrm{K}^{+}$ATPase pump at the cardiac muscular fibers, a condition that causes a reduction in myocardia electric activity. Inhibition of $\mathrm{Na}^{+} / \mathrm{K}^{+}$ ATP ase pump by the cardiac glycosides results in the increased concentration of intracellular sodium, leading to the influx of calcium in the intracellular compartment and its release to the sarcoplasm. The increased concentration of free calcium in sarcoplasm augments the contraction force of the myocardium and the positive inotropic effect (JOUBERT, 1989). This event indirectly induces a decreased heart electric conduction by increasing the vagus nerve tonicity (KATZUNG \& PARMLEY, 1998); this could explain the decreased heart frequency at T4h reported in the present experiment.

According to KELLERMANN et al. (2005), the isolated toxic principle of $N$. oleander belongs to the group of cardiac glycosides, known to affect contractility and impulse conduction in the cardiac fiber. High doses of cardiotoxic glycosides cause a substantial decrease in conduction rate, called negative dromotropic effect, resulting in severe atrium-ventricular dissociation, with consequent first-, second-, and third-degree blockade. The increase in PR interval observed in the present study; although not significant, is probably due to this action of the toxic principle, indicating a first-degree atriumventricular block.

Intravenous glucose treatment was established in the experimental protocol because of the hypoglycemic characteristics of oleander extracts, which had been studied experimentally for this therapeutic purpose. MWAFY \& YASSIN (2011) demonstrated blood glucose levels in diabetic rats treated with $N$. oleander extract to be lower than those in control rats. PAGE \& MURTAUGH (2015) described the successful treatment of a dog poisoned by $N$. oleander and presenting the classical symptoms, including hypoglycemia, as a pertinent clinical finding. Blood glucose measurement should be a part of the treatment protocol for a patient intoxicated by $N$. oleander. This was not established in the present study, which is a limitation of the research.

Toxic compounds of the plant, due to their chemical and pharmacokinetic similarity to digoxin, have some properties that define their biological availability and have an influence on the level of animal intoxication. A less liposoluble substance would have a higher fat deposition and need more time to be eliminated, while the substances could have a lower absorption when administered with the food. The substances bind to albumin to a lesser extent in animals with hypoalbuminemia, which resulted in higher blood concentrations of the substance. In addition, hypocalcemia could decrease the competition on the binding sites, allowing higher substance concentration in blood (BROWN et al., 2007).

\section{CONCLUSION}

The present study demonstrated that dogs can be poisoned with $0.25 \mathrm{~g} / \mathrm{kg}$ single dose of ground $N$. oleander fresh leaves, and this concentration is sufficient to cause a moderate intoxication, with nonspecific clinical alterations mainly related to the digestive system, cardiac rhythm, and blood pressure. This indicated the importance of considering this type of intoxication in the list of differential diagnoses of the routine of small animals, which can be fatal for the patient.

\section{BIOETHICS AND BIOSSECURITY COMMITTEE APPROVAL}

The dogs used in this study were from the institution's kennel. Protocol of the committee of ethics 006357-09.

\section{ACKNOWLEDGEMENTS}

Financial support: Conselho Nacional de Desenvolviment Científico e Tecnológico (CNPq).

\section{REFERENCES}

ASLANI, M.R. et al. Experimental oleander (Nerium oleander) poisoning in goats: a clinical and pathological study. Iranian Journal of Veterinary Research, v.8, p.58-63, 2007. Available from: <http://www. sid.ir/en/vewssid/j_pdf/102320070108.pdf>. Accessed: May 20, 2016.

BROWN, S. et al. Guidelines for the identification, evaluation and management of systemic hypertension in dogs and cats. Journal of Veterinary Internal Medicine, v.21, p.542-558, 2007. Available from: $<$ http://www.ivis.org/proceedings/acvim/consensus $>$. Accessed: May 10, 2016. doi: 0891-6640/07/2103-0028/\$3.00/0.

CLARCK, R. et al. Digoxin-specific Fab fragments in the treatment of oleander toxicity in a canine model. Annals of Emergency Medicine, v.20, p.1073-1077, 1991. Available from: <http://www.sciencedirect. com/science/article/pii/S0196064405813551>. Accessed: May 10, 2016. doi: 10.1016/S0196-0644(05)81355-1.

DURHAM, H.E. Arterial blood pressure measurement. Veterinary Technician, v.26, n.5, p.324-339, 2005. Available from: <http:// www.vetfolio.com/arterial-blood-pressure-measurement $>$. Accessed: May 20, 2016.

GAINS, M.J. et al. Comparison of direct and indirect blood pressure measurements in anesthetized dogs. Canadian Journal of Veterinary Research, v.59, p.238-240, 1995. Available from: $<$ https://www.ncbi. nlm.nih.gov/pmc/articles/PMC1263773/>. Accessed: May 13, 2016. 
GALEY, F.D. Diagnosis of oleander poisoning in livestock. Journal Veterinary Diagnostic Investigation, v.8, p.358-364, 1996. Available from: $<$ https://www.ncbi.nlm.nih.gov/pubmed/8844581>. Accessed: May 13, 2016.

HABERMAN, C.E. et al. Evaluation of oscillometric and Doppler ultrasonic methods of indirect blood pressure estimation in conscious dogs. Canadian Journal of Veterinary Research, v.70, p.211-217, 2006. Available from: <https:/www.ncbi.nlm.nih.gov/ pubmed/16850944>. Accessed: May 10, 2016.

HUGHES, K.J. et al. Suspected Nerium oleander poisoning in a horse. Australian Veterinary Journal, v.80, p.412-415, 2002. Available from: <https://www.ncbi.nlm.nih.gov/pubmed/12222602>. Accessed: May 10, 2016. doi: 10.1111/j.1751-0813.2002.tb11000.x.

IBRAHIM, A. et al. A fatal case of oleandrin poisoning. Forensic Science International, v.179, p.31-36, 2008. Available from: $<$ http:// www.sciencedirect.com/science/article/pii/S0379073808002284> Accessed: May 15, 2016. doi: 10.1016/j.forsciint.2008.05.002.

JOUBERT, J.P.J. Cardiac glicosides. In: CHEEKE, P.R. Toxicants of plant origin. Boca Raton: CRC Press Book, 1989. p.61-96.

KATZUNG, B.G.; PARMLEY, W.W. Cardiac glycosides and other drugs used in congestive heart failure. Basic and Clinical Pharmacology, 1998 p.197-216. Available from: <https:/quizlet.com/5634451/chapt24drugsfor-heart-failure>. Accessed: May 12, 2016.

KELLERMAN, T.S. et al. Plant poisoning and mycotoxicoses of livestock in Southern Africa. 2.ed. Cape Town: Oxford University, 2005. 310p.

KNIGHT, A.P. Oleander poisoning. Compendium on Continuing Education for the Practicing Veterinarian, v.10, p.262-263. 1988.

LANGFORD, S.D.; BOOR, P.J. Oleander toxicity: an examination of human and animal exposures. Toxicology, v.109, p.1-13, 1996. Available from: <http://www.sciencedirect.com/science/ article/pii/0300483X9503296R>. Accessed: May 13, 2016. doi: 10.1016/0300-483X(95)03296-R.

LYNN, M.; SAFDAR, A. An overview of potentially lifethreatening poisonous plants in dogs and cats. Journal of
Veterinary Emergency and Critical Care, v.16, p.25-33, 2006. Available from: <http://onlinelibrary.wiley.com/doi/10.1111/ j.1476-4431.2005.00151.x/abstract>. Acessed: May 13, 2016. doi: 10.1111/j.1476-4431.2005.00151.x.

MARTINEZ, B.R. et al. Intoxicación por Nerium oleander (baladre) de los casos clínicos. Farmacia Hospitalaria, v.31, p.128-136, 2007. Available from: <http://www.aulamedica.es/gdcr/index.php/fh/article/ view/930>. Accessed: May 13, 2016. doi: 1130-6343/2007/31/2/128.

MERRETT, D. Digoxin therapy. Australian Veterinary Journal, v.78, p.612-615, 2000. Available from: <http://onlinelibrary.wiley. com/doi/10.1111/j.1751-0813.2000.tb11932.x/abstract>. Accessed: May 13, 2016. doi: 10.1111/j.1751-0813.2000.tb11932.x.

MWAFY, S.N.; YASSIN, M.M. Antidiabetic activity evaluation of glimepiride and Nerium oleander extract on insulin, glucose levels and some liver enzymes activities in experimental diabetic rat model. Pakistan Journal of Biological Sciences, v.14, n.21, p.984-90, 2011. Available from: < https://www.ncbi.nlm.nih.gov/pubmed/22514888>. Accessed: May 10, 2016. doi: 10.3923/pjbs.2011.984.990.

PAGE, C.; MURTAUGH, R.J. Hypoglycemia associated with Oleander toxicity in a dog. Journal of Medical Toxicology, v.11, p.141-143, 2015. Available from: <https:/www.ncbi.nlm.nih. gov/pubmed/25252802>. Accessed: May 10, 2016. doi: 10.1007/ s13181-014-0436-x.

PLUMB, D.C. Veterinary drug handbook. 3.ed. Iowa: Iowa State University, 1999. 750p.

SHIH, A. et al. Evaluation of an indirect oscillometric blood pressure monitor in normotensive and hypotensive anesthetized dogs. Journal of Veterinary Emergency and Critical Care, v.20, n.3, p.313-318, 2010. Available from: <https://www.ncbi.nlm.nih.gov/pubmed/20636984>. Accessed: May 13, 2016. doi: 10.1111/j.1476-4431.2010.00536.x.

SOTO-BLANCO, B. etal. Acute cattle intoxication from Nerium oleander pods. Tropical Animal Health and Production, v.38, p.451-454, 2006. Available from: <https://www.ncbi.nlm.nih.gov/pubmed/17243471>. Accessed: May 13, 2016. doi: 10.1007/s11250-006-4400-x.

TILLEY,L.P. Essentials of canine and feline electrocardiography. 3.ed. Philadelphia: Lea \& Febiger, 1992. 470p. 